\title{
Roller chopping effects on tamaulipan scrub community composition
}

\author{
JASON R. SCHINDLER AND TIMOTHY E. FULBRIGHT
}

Authors are Wildlife Biologist, Blanton and Associates, Inc., Lakeway Centre Court, Suite 200, Austin, Texas 78734, and Meadow's Professor, Caesar Kleberg Wildife Research Institute, MSC 218, Texas A\&M University-Kingsville, Kingsville, Texas 78363. At the time of the research, authors were graduate Research Assistant and Professor, Department of Animal \& Wildlife Sciences, Texas A\&M University-Kingsville, Kingsville, Texas. Send reprint requests to Fulbright.

\begin{abstract}
Palatability of shrub sprouts to white-tailed deer (Odocoileus virginianus Raf.) differs among species, which causes selective browsing and can shift shrub species composition to dominance by less palatable species. The hypothesis was tested that differences in palatability of new sprouts among shrub species following roller chopping small (4 ha) patches within a shrubland matrix would result in a shift in shrub species composition within the patches toward less palatable species. Relative density and relative canopy cover of all woody species in plots 9 years after 1 roller chopping treatment, in plots 3 years after 2 roller chopping treatments, and in untreated plots were estimated. Relative density of blackbrush acacia (Acacia rigidula Benth.) was 3 times greater and relative canopy cover was 12 times greater 9 years after the first roller chopping treatment compared to untreated plots, but relative density and relative canopy cover of blackbrush acacia in roller chopped plots were similar to relative density and relative canopy cover in untreated plots 3 years after the second roller chopping treatment. Relative canopy cover of spiny hackberry (Celtis pallida Torr.) in plots roller chopped in 1989 and 1995 was higher than in untreated plots. Relative density and canopy cover of all other species were similar between roller chopped and untreated plots. Shrub community composition 9 years after 1 roller chopping treatment or 3 years after 2 roller chopping treatments in the subtropical thornscrub communities in southern Texas did not shift toward greater dominance of less palatable species.
\end{abstract}

Key Words: Acacia rigidula, blackbrush acacia, brush management, Celtis pallida, spiny hackberry, white-tailed deer

Many shrub species produce sprouts from stems, crowns, and roots to replace above-ground tissue removed by roller chopping, mowing, and other top-growth removal treatments (Scifres 1980, Fulbright and Taylor 2001). Top growth removal of woody plants in small patches within a surrounding matrix of shrubland results in intense browsing on newly-produced sprouts by white-tailed deer (Odocoileus virginianus Raf.) (Stewart et al. 2000). Whitetailed deer concentrate feeding activity in clearings created by

Research was funded by the Rob and Bessie Welder Wildlife Foundation and the Caesar Kleberg Foundation for Wildlife Conservation. This is publication number 584 from the Rob and Bessie Welder Wildlife Foundation and publication number 02-111 from the Caesar Kleberg Wildlife Research Institute.

Manuscript accepted 23 Dec. 02.
Resumen

La palatabilidad de los rebrotes de diferentes arbustos para el venado cola blanca (Odocoileus virginianus Raf.) difiere entre distintas especies, lo cual causa ramoneo selectivo de los venados y puede provocar la dominancia de las especies menos palatables. La hipótesis probada fue que las diferencias en palatabilidad de rebrotes entre especies de arbustos después del roleo de pequeñas áreas (4 ha) dentro de el matorral resultaría en un cambio en la composición de las especies de arbustos en las áreas roleadas favoreciendo las especies menos palatables. Se estimó densidad relativa y cobertura aérea relativa para todas las especies arbustivas en las parcelas roleadas 9 años después de 1 tratamiento de roleo, 3 años después de 2 roleos, y en parcelas sin rolear (testigo). La densidad relativa y la cobertura relativa de chaparro prieto (Acacia ridigula Benth.) fue 3 y 12 veces superior, respectivamente, al tratamiento testigo, sin embargo, las mismas variables reapuesta fueron similares para el tratamiento testigo y el tratamiento de 2 roleos 3 años después del segundo roleo. La cobertura relativa de granjeno (Celtis pallida Torr.) en las parcelas que se rolearon en 1989 y 1995 fue superior que en el tratamiento testigo. La densidad relativa y cobertura aérea de todas las demás especies arbustivas fueron similares entre los tratamientos de roleo y el testigo. La composición de la comunidad arbustiva 9 años después del un tratamiento de roleo o 3 años después de 2 roleos en comunidades de matorral espinoso subtropical en el Sur de Texas no provocó una mayor dominancia de las especies menos palatables.

mechanical top removal and may travel from adjacent areas to utilize habitats with clearings (Naderman 1979, Bozzo et al. 1992). White-tailed deer fecal-group density averaged 8 times higher in 30 to 125 ha clearings created by shrub top growth removal than in adjacent uncleared shrubland (Bozzo et al. 1992). Intensive use by white-tailed deer of patches created by top growth removal is partly a result of the presence of new sprouts produced by shrubs (Stewart et al. 2000). Sprouts temporarily contain higher nutrient levels and are more accessible to herbivores than the canopy of mature, untreated plants (Scifres 1980, Vallentine 1980, Yoakum et al. 1980).

Not only are patches created by top removal more heavily used by deer, but certain shrub species are more palatable after top removal than others, resulting in intense browsing pressure on the palatable shrubs. Relative preference of spiny hackberry (Celtis pallida Torr.), brasil (Condalia hookeri M. C. Johnst.), and agari- 
to [Mahonia trifoliolata (Moric.) Fedde], increased $13,217 \%, 2,221 \%$, and $1,758 \%$, respectively, after top growth removal (Powell and Box 1966). In contrast, relative preference of blackbrush acacia (Acacia rigidula Benth.), huisache ( $A$. smallii Isely), Texas persimmon (Diospyros texana Scheele), and twisted acacia [A. schaffneri (S. Wats) Herm.] each decreased $71 \%$.

Differences in palatability induce selective browsing by herbivores (Westoby 1974, Bryant et al. 1991), which in turn mediates the impacts of herbivory on plant species populations (Illius et al. 1999) and on shrub community composition. Less palatable species theoretically should have a competitive advantage over highly palatable species that are continually browsed by herbivores and should increase in relative abundance in the plant community (Bryant et al. 1991).

Repeated defoliation of guajillo (Acacia berlandieri Benth.) results in mortality of the defoliated stems (Forbes et al. 1995). Repeated removal of photosynthetic tissue from sprouts produced to replace aboveground parts removed by mechanical means may inhibit survival and re-establishment of highly palatable shrubs. Because preference of shrub sprouts differs dramatically from preference of mature untreated plants, and because the amplitude of these differences varies among species, top growth removal may shift the shrub community composition to dominance by less palatable species because of increased browsing pressure on highly palatable species and reduced browsing pressure on less palatable species. Decreased shrub species diversity 7 to 30 years after mechanical top growth removal has been reported (Fulbright 1987, Fulbright and Beasom 1987), but the mechanisms explaining the loss of species remain unclear.

The hypothesis was tested that the longterm result of roller chopping small (4 ha) patches within a shrubland matrix would be a shift in shrub species composition within the patches. Roller chopping was predicted to result in increased relative density and relative canopy cover of species reported to have lowered relative preference after top growth removal (Powell and Box 1966), while species highly preferred after top growth removal were predicted to decrease in relative density and relative canopy cover after roller chopping.

\section{Materials and Methods}

\section{Study Area}

The study was conducted on the Rob and Bessie Welder Wildlife Foundation Refuge, which consists of 3,158 ha of native rangeland $70 \mathrm{~km}$ north of Corpus Christi in San Patricio County, Tex. $\left(28^{\circ}\right.$ 6' $\left.49^{\prime \prime} \mathrm{N}, 97^{\circ} 25^{\prime} 00^{\prime \prime} \mathrm{W}\right)$. The refuge lies adjacent to the Aransas River at about $12 \mathrm{~m}$ above sea level, with a slope gradient $<1 \%$. Climate is characterized as subtropical with hot summers and mild winters (Box 1961). Average length of the frost-free growing season was 300 days. The average annual maximum and minimum temperatures (1982 to 1998 ) were 27 and $17^{\circ} \mathrm{C}$, respectively (Rob and Bessie Welder Wildlife Foundation, Refuge Records). Average annual rainfall (1956 to 1998) recorded on the refuge was $89 \mathrm{~cm}$, with bimodal peaks occurring in spring and fall. Average rainfall from 1989 through 1997 was $84 \mathrm{~cm}$, $94 \%$ of the annual average. Average rainfall from 1995 through 1997 was $85 \mathrm{~cm}$, $95 \%$ of the annual average.

Two major plant communities were present in the study area: a chaparral-mixed grass community, with a variety of dominant shrub species, and a live oak-chaparral community dominated by live oak (Quercus virginiana Mill.), with a shrub community similar in species composition to the chaparral-mixed grass community (Drawe et al. 1978). Soils included Victoria clay (Udic Pellustert), Papalote fine sandy loam (Aquic Paleustalf), Orelia fine sandy loam (Typic Ochraqualf), and Orelia sandy clay loam (Typic Ochraqualf) (Guckian and Garcia 1979). The study area averaged $26 \pm 3(0$ mean \pm $\mathrm{SE}, \mathrm{n}=21)$ individual white-tailed deer per $\mathrm{km}^{2}$ (Rob and Bessie Welder Wildlife Foundation Refuge Census Records, 1975 to 1995).

\section{Experimental Design}

A randomized, complete-block design (blocking based on soil differences) with each block (replicate) consisting of a 4-ha $(100 \times 400 \mathrm{~m})$ roller chopped plot and an adjacent 4-ha untreated plot selected randomly east or west of the roller chopped plot was used in the study. A roller chopper is a large cylindrical metal drum with metal blades mounted parallel to its axis. The roller chopper is pulled by a crawler tractor and severs stems of woody plants, with up to 6-in diameters, at the soil surface. Four blocks contained treatment plots that were roller chopped once in 1989 and untreated control plots. Five blocks contained treatment plots that were roller chopped twice, in 1989 and in 1995 , and untreated control plots. Data from plots roller chopped once in 1989 and adjacent controls, and data from plots roller chopped twice, in 1989 and 1995, and adjacent controls were analyzed as 2 separate randomized, complete-block experiments. All measurements were taken in 1998, 9 years after the first roller chopping treatment and 3 years after the second roller chopping treatment.

\section{Data Collection and Analysis}

Density and percentage canopy cover estimates were made during June 1998 in plots roller chopped in 1989 and in corresponding untreated plots to determine long-term ( 9 years after 1 roller chopping treatment) effects of roller chopping on shrub community composition. Density and percentage canopy cover estimates in plots roller chopped in both 1989 and 1995 and in corresponding untreated plots were made during February 1998 (3 years after the second roller chopping treatment). Densities of all shrub and halfshrub species [nomenclature follows Hatch et al. (1990)] were estimated by counting the number of individual plants rooted in $12,1 \times 10-\mathrm{m}$ belt transects located perpendicular to each side of the common boundary of roller chopped and untreated plots. An individual plant consisted of a distinct group of sprouts originating from basal crowns of multi-stemmed species, or ramets originating from lateral roots. Transects were placed randomly between 10 and $90 \mathrm{~m}$ from each side of the boundary. Percentage canopy cover of each shrub and half-shrub species was estimated with the line-intercept technique (Canfield 1941) along a 10-m line transect at the south border of each belt transect.

Density and percentage canopy cover data were converted to relative density and relative canopy cover by dividing the absolute density and canopy cover for each species by the total density and canopy cover of all species combined within each experimental unit. Relative density and relative canopy cover for each species were compared between roller chopped and untreated plots using analysis of variance (ANOVA) for a randomized, complete-block design with treatment as the main effect (SAS Institute, Inc. 1989). The outcome of analyses of variance with arcsine transformed relative density and canopy cover means was similar to the outcome with non-transformed values, so statistical analyses were conducted with non-transformed values. Differences were considered significant at the 0.05 level. 
Species composing $<1 \%$ of the shrub community in both the roller chopped and untreated plots were not included in comparisons. Linear regression was used to determine the relationship between changes in relative densities of shrub species after roller chopping and changes in relative preference after top growth removal based on preference values reported in Powell and Box (1966). The change in relative preference for each species was calculated by subtracting the relative preference of a species after mowing from the relative preference of the species in untreated plots and dividing the result by the relative preference of the species in untreated plots. In the current study, the change in relative density of each species was calculated by subtracting the relative density of a species in roller chopped plots from the relative density of the species in untreated plots and dividing the result by the relative density of the species in untreated plots.

\section{Results}

\section{Relative Density}

Twenty woody species were recorded in roller chopped and untreated plots (Table 1). Blackbrush acacia, brasil, honey mesquite, huisache, lime pricklyash, spiny hackberry, and Texas persimmon composed $88 \pm 18 \%$ and $82 \pm 31 \%$ (mean \pm $\mathrm{SE}, \mathrm{n}=4$ ) of the shrub community in plots roller chopped in 1989 and in untreated plots, respectively (Table 2). Relative density of blackbrush acacia was 3 times higher $(\mathrm{P}=0.005)$ in plots roller chopped in 1989 compared to untreated plots. Relative densities of all other recorded species, regardless of relative preference after top growth removal, were similar $(\mathrm{P}$ $>0.05$ ) between roller chopped and untreated plots. There was no significant linear relationship $\left(\mathrm{R}^{2}=0.004, \mathrm{P}=0.879\right)$ between changes in relative densities of shrub species 9 years after 1 roller chopping treatment and changes in relative preference after top growth removal, based on preference values reported by Powell and Box (1966).

Blackbrush acacia, brasil, honey mesquite, huisache, lime pricklyash, spiny hackberry, and Texas persimmon composed $87 \pm 22 \%$ and $74 \pm 18 \%$ (mean \pm $\mathrm{SE}, \mathrm{n}=5$ ) of the shrub community on plots roller chopped in 1989 and 1995 and on untreated plots, respectively. Relative densities of all shrub and half-shrub species on roller chopped and untreated plots were similar $(\mathrm{P}>0.05) 3$ years after

Table 1. Scientific and common names of all shrub and half-shrub species recorded in the shrub community on the Rob and Bessie Welder Wildlife Foundation Refuge, San Patricio County, Tex., 1998. Nomenclature follows Hatch et al. (1990).

\begin{tabular}{ll}
\hline \hline Scientific name & Common name \\
\hline Acacia rigidula Benth. & Blackbrush acacia \\
Acacia smallii Isely & Huisache \\
Amyris texana (Buckl.) P. Wils. & Chapatillo \\
Bumelia lanuginosa (Michx.) Pers. & Coma \\
Celtis pallida Torr. & Spiny hackberry \\
Condalia hookeri M. C. Johnst. & Brasil \\
Diospyros texana Scheele & Texas persimmon \\
Forestiera angustifolia Torr. & Narrowleaf Forestiera \\
Guaiacum angustifolium Engelm. & Guayacan \\
Lantana horrida Kunth. In H.B.K. & Common lantana \\
Lycium berlandieri Dunal & Berlandier wolfberry \\
Mahonia trifoliolata (Moric.) Fedde & Agarito \\
Opuntia leptocaulis DC. & Tasajillo \\
Opuntia lindheimeri Engelm. & Texas prickly pear \\
Parkinsonia aculeata L. & Retama \\
Prosopis glandulosa Torr. & Honey mesquite \\
Quercus virginiana Mill. & Live oak \\
Yucca treculeana Carriere & Spanish dagger \\
Zanthoxylum fagara (L.) Sarg. & Lime pricklyash \\
Zizyphus obtusifolia (T. \& G.) Gray & Lotebush \\
\hline
\end{tabular}

the second roller chopping treatment. There was no significant linear relationship $\left(R^{2}=0.34, P=0.100\right)$ between changes in relative densities of shrub species 3 years after 2 roller chopping treatments and changes in relative preference after top growth removal, based on preference values reported by Powell and Box (1966).

\section{Relative Canopy Cover}

Absolute canopy cover of shrubs did not differ $(\mathrm{P}=0.554)$ between plots roller chopped in $1989(78 \pm 7 \%)$ and untreated plots $(81 \pm 2 \%)$. Absolute woody canopy cover in plots roller chopped in 1989 and $1995(35 \pm 6 \%)$ was lower $(P=0.006)$ than in untreated plots $(71 \pm 8 \%)$. Relative canopy cover of blackbrush acacia in plots roller chopped in 1989 was significantly higher $(P=0.006)$ than in untreated plots (Table 3), which corresponded with the increase in relative density of blackbrush acacia in plots roller chopped in 1989. Relative canopy cover of spiny hackberry in plots roller chopped in 1989 and 1995 was greater $(P=0.025)$ than in untreated plots. Relative canopy cover of all other shrub species was similar $(P>0.05)$ between roller chopped and untreated plots.

\section{Discussion and Conclusions}

Shrub community composition 9 years after 1 roller chopping treatment and 3 years after 2 roller chopping treatments could not be predicted based on changes in relative preference reported by Powell and Box (1966) after top growth removal. The only exception was that blackbrush acacia, a species that decreased in relative preference after top growth removal, composed a larger percentage of the shrub community 9 years after 1 roller chopping treatment compared to untreated communities. Roller chopping on the Welder Wildlife Refuge reduced overall shrub canopy cover for at least 3 years but not for 9 years, which supports earlier reports that shrub canopy cover is decreased for only 2 to 3 years after roller chopping (Welch et al. 1985, Bozzo et al. 1992).

There are several possible reasons why changes in relative preference after top growth removal failed to predict long-term shrub community composition after roller chopping in the subtropical thornscrub of southern Texas. First, shrub sprouts produced following top removal are more palatable than browse from untreated plants only for a short time following top removal. Stewart et al. (2000) attributed increased white-tailed deer use of areas on the Welder Wildlife Refuge immediately after roller chopping to the presence of lush shrub sprouts. However, deer use of these areas declined as the sprouts matured, thus alleviating browsing intensity. Palatability of newly-produced sprouts declines rapidly. For example, sprouts from burned spiny hackberry plants were browsed more heavily than twigs from unburned plants for only 9 weeks after a 
Table 2. Mean values ${ }^{1}$ of relative density $(\%)$ of all shrub and half-shrub species in plots that were roller chopped once in 1989 ( $n=4$ plots per treatment) and twice, in 1989 and in 1995 ( $n=5$ plots per treatment), compared to untreated plots on the Rob and Bessie Welder Wildlife Foundation Refuge, San Patricio County, Tex., 1998.

\begin{tabular}{|c|c|c|c|c|c|c|c|c|c|c|c|}
\hline \multirow{3}{*}{ Species } & \multirow{3}{*}{ Preference $^{2}$} & \multirow{2}{*}{\multicolumn{4}{|c|}{ Roller chopped }} & \multicolumn{6}{|c|}{1989 and 1995} \\
\hline & & & & & & \multirow[b]{2}{*}{$\mathrm{P}$} & \multicolumn{2}{|c|}{ Roller chopped } & \multicolumn{2}{|c|}{ Untreated } & \multirow[b]{2}{*}{$\mathrm{P}$} \\
\hline & & (\%) & SE & $(\%)$ & SE & & $(\%)$ & SE & $(\%)$ & SE & \\
\hline Honey mesquite & 17 & 25 & 6 & 35 & 13 & 0.325 & 23 & 7 & 37 & 7 & 0.156 \\
\hline Lime pricklyash & 192 & 16 & 2 & 18 & 3 & 0.109 & 23 & 3 & 13 & 4 & 0.074 \\
\hline Blackbrush acacia & -71 & 16 & 3 & 5 & 4 & 0.005 & 8 & 3 & 4 & 2 & 0.141 \\
\hline Spiny hackberry & 13,217 & 12 & 3 & 7 & 3 & 0.180 & 14 & 4 & 6 & 1 & 0.135 \\
\hline Texas persimmon & -71 & 7 & 1 & 7 & 3 & 0.963 & 4 & 1 & 3 & 1 & 0.730 \\
\hline Huisache & -59 & 6 & 1 & 6 & 3 & 0.982 & 9 & 3 & 7 & 2 & 0.735 \\
\hline Brasil & 2,221 & 6 & 2 & 4 & 2 & 0.601 & 6 & 1 & 4 & 1 & 0.246 \\
\hline Lotebush & 31 & 5 & 3 & 1 & 1 & 0.266 & 1 & 1 & 1 & 1 & 0.700 \\
\hline Agarito & 1,758 & 3 & 1 & 3 & 2 & 0.960 & 3 & 1 & 4 & 2 & 0.693 \\
\hline Chapatillo & $\mathrm{NR}^{3}$ & 3 & 1 & 7 & 3 & 0.280 & $<1$ & $<1$ & 2 & 1 & 0.388 \\
\hline Tasajillo & NR & 2 & 1 & 5 & 4 & 0.547 & 1 & 1 & 6 & 4 & 0.296 \\
\hline Texas prickly pear & NR & 1 & $<1$ & $<1$ & $<1$ & 0.884 & 1 & 1 & 1 & 1 & 0.843 \\
\hline Narrowleaf forestiera & NR & $<1$ & $<1$ & 3 & 2 & 0.240 & $<1$ & $<1$ & 1 & 1 & 0.178 \\
\hline Berlandier wolfberry ${ }^{4}$ & NR & $<1$ & $<1$ & $<1$ & $<1$ & & 3 & 1 & 5 & 1 & 0.354 \\
\hline Live oak ${ }^{4}$ & NR & 0 & & 0 & & & 4 & 4 & 0 & & 0.374 \\
\hline Retama $^{4}$ & NR & 0 & & 0 & & & 0 & & 3 & 3 & 0.334 \\
\hline $\mathrm{Coma}^{4}$ & NR & 0 & & 0 & & & 0 & & 1 & 1 & 0.374 \\
\hline Common lantana ${ }^{4}$ & NR & 0 & & 0 & & & $<1$ & $<1$ & $<1$ & $<1$ & \\
\hline Guayacan $^{4}$ & NR & 0 & & 0 & & & $<1$ & $<1$ & 0 & & \\
\hline
\end{tabular}

Data were analyzed using analysis of variance (ANOVA) for a randomized complete block design.

${ }^{2}$ Change in relative preference (\%) for white-tailed deer and cattle during the first growing season after mowing. Powell and Box (1966) calculated preference values of shrub species in untreated plots and after mowing by multiplying percent utilization by frequency of use at a deer density of 1 deer per 2.4 ha. In the current study, relative preference of each species was calculated from those preference values by dividing the preference value of a species by the sum of the preference values of all species reported. The change in relative preference for each species was calculated by subtracting the relative preference of a species after mowing from the relative preference of the species in untreated plots and dividing the result by the relative preference of the species in untreated plots.

${ }^{3} \mathrm{NR}=$ Not reported by Powell and Box (1966).

${ }^{4}$ Species with relative density $<1 \%$ in roller chopped and untreated plots were not analyzed.

Table 3. Mean values ${ }^{1}$ of relative canopy cover $(\%)$ of all shrub and half-shrub species in plots that were roller chopped once in $1989(\mathrm{n}=4$ plots per treatment) and twice, in 1989 and in 1995 ( $n=5$ plots per treatment), compared to untreated plots on the Rob and Bessie Welder Wildlife Foundation Refuge, San Patricio County, Tex., 1998.

\begin{tabular}{|c|c|c|c|c|c|c|c|c|c|c|}
\hline \multirow{3}{*}{ Species } & \multicolumn{4}{|c|}{1989} & \multicolumn{6}{|c|}{1989 and 1995} \\
\hline & \multicolumn{2}{|c|}{ Roller chopped } & \multicolumn{2}{|c|}{ Untreated } & \multirow[b]{2}{*}{$P$} & \multicolumn{2}{|c|}{ Roller chopped } & \multicolumn{2}{|c|}{ Untreated } & \multirow[b]{2}{*}{$P$} \\
\hline & $(\%)$ & SE & $(\%)$ & SE & & $(\%)$ & SE & $(\%)$ & SE & \\
\hline Honey mesquite & 35 & 5 & 50 & 5 & 0.205 & 32 & 6 & 45 & 9 & 0.107 \\
\hline Lime pricklyash & 15 & 2 & 14 & 3 & 0.959 & 16 & 2 & 11 & 3 & 0.311 \\
\hline Blackbrush acacia & 12 & 2 & 1 & 1 & 0.006 & 9 & 3 & 5 & 2 & 0.222 \\
\hline Spiny hackberry & 11 & 3 & 7 & 2 & 0.209 & 12 & 2 & 2 & 1 & 0.025 \\
\hline Texas persimmon & 8 & 2 & 9 & 4 & 0.751 & 4 & 1 & 5 & 2 & 0.494 \\
\hline Huisache & 7 & 3 & 5 & 3 & 0.751 & 9 & 4 & 13 & 1 & 0.287 \\
\hline Brasil & 9 & 2 & 10 & 2 & 0.824 & 9 & 3 & 9 & 3 & 0.962 \\
\hline Lotebush $^{2}$ & $<1$ & $<1$ & $<1$ & $<1$ & & $<1$ & $<1$ & $<1$ & $<1$ & \\
\hline Agarito & 2 & 1 & 2 & 1 & 0.996 & 3 & 1 & 2 & 1 & 0.561 \\
\hline Chapatillo $^{2}$ & $<1$ & $<1$ & 1 & $<1$ & 0.596 & $<1$ & $<1$ & $<1$ & $<1$ & \\
\hline Tasajillo & 1 & $<1$ & $<1$ & $<1$ & 0.210 & $<1$ & $<1$ & 3 & 3 & 0.416 \\
\hline Texas prickly pear ${ }^{2}$ & 1 & 1 & 0 & & 0.391 & $<1$ & $<1$ & $<1$ & $<1$ & \\
\hline Narrowleaf forestiera & $<1$ & $<1$ & 2 & 1 & 0.256 & 1 & 1 & $<1$ & $<1$ & 0.411 \\
\hline Berlandier wolfberry ${ }^{2}$ & 0 & & 0 & & & 1 & 1 & 2 & 1 & 0.565 \\
\hline Live oak ${ }^{2}$ & 0 & & 0 & & & 1 & 1 & 0 & & 0.374 \\
\hline $\operatorname{Retama}^{2}$ & 0 & & 0 & & & 0 & & 1 & 1 & 0.374 \\
\hline Common lantana ${ }^{2}$ & 0 & & 0 & & & $<1$ & $<1$ & 0 & & \\
\hline $\mathrm{Coma}^{2}$ & 0 & & 0 & & & 0 & & $<1$ & $<1$ & \\
\hline Guayacan $^{2}$ & 0 & & 0 & & & $<1$ & $<1$ & 0 & & \\
\hline Spanish dagger $^{2}$ & 0 & & 0 & & & $<1$ & $<1$ & 0 & & \\
\hline
\end{tabular}

Data were analyzed using analysis of variance (ANOVA) for a randomized complete block design

${ }^{2}$ Species with relative canopy cover $<1 \%$ in roller chopped and untreated plots were not analyzed. 
prescribed fire (Schindler 2000). Whitetailed deer on the Welder Wildlife Refuge consume a diverse diet that is dominated by forbs and use browse heavily only during periods of drought and low herbaceous plant availability (Chamrad and Box 1968, Drawe 1968). Therefore, even with the temporary increase in browsing intensity in cleared patches, browsing by deer may not be intense enough to significantly impact populations of highly palatable shrubs.

Second, the ability to tolerate or resist browsing following top growth removal may prevent shrubs that are highly palatable after top growth removal from being damaged by herbivory. Most of the shrub species in our study produce sprouts from crowns and roots after mechanical top growth removal (Scifres 1980, Scifres and Hamilton 1993), resulting in plants with multiple stems. In this way, the shrubs can actually increase biomass production and reduce the impacts of herbivory because the biomass eaten relative to the available biomass decreases. Density of shrub species in boreal forests of Isle Royale National Park was unaffected by moose browsing, possibly because of their ability to increase basal sprouting and develop lateral buds after apical dominance was disturbed by browsing (Snyder and Janke 1976). Increased stem production may create the potential for long-term increased seed production. Long-term density of highly palatable browse species after top growth removal may not decrease in part because of increased seed production and subsequent juvenile recruitment.

Although spiny hackberry is highly palatable to white-tailed deer, this species has been described as an invader following brush management (Scifres et al. 1976, Drawe 1977) and may increase in shrub community composition after top growth removal (Box and Powell 1965, Fulbright and Beasom 1987). Spiny hackberry increases stem production after top growth removal (Asah et al. 1987, Flinn et al. 1992), which probably helps protect this species from decreasing in abundance after roller chopping. In addition, the shrub appears to be highly tolerant of defoliation. Standing crop of spiny hackberry leaves and stems 13 months after top growth removal was unaffected by complete removal of regrowth at 3 and 6 months after top growth removal (Asah et al. 1987).

Third, juvenile stages of many shrubs are more protected by chemical and physical antiherbivore defenses than the conspecific mature stage (Bryant and
Julkunen-Tiitto 1995). Juvenile quaking aspen (Populus tremuloides Michx.) plants in the Great Basin of North America are more chemically defended than mature plants (Basey et al. 1988). Juvenile plants of Alaska paper birch (Betula papyrifera Marsh) have high concentrations of certain terpene resins that are not present in mature plants (Reichardt et al. 1984). If juvenile stages of south Texas shrub species have increased antiherbivore defenses, then densities of shrub species may not be altered by top growth removal and subsequent herbivory. Removing top growth of mature shrubs can cause reversion to the more heavily defended juvenile stage (Chapin et al. 1985, Bryant et al. 1992). Fresh regrowth of shrubs after roller chopping may invest more into chemical and physical defenses. Sprouts produced by guajillo (Acacia berlandieri Benth.) after pruning have higher concentrations of tyramine and N-methyl- $\beta$ phenethylamine than mature growth (Forbes et al. 1995).

Mammalian herbivory in general will not cause high mortality of woody species once they have been established, with possible exceptions occurring under intense herbivory on low-productivity sites (Edenius et al. 1995). Relative preference after top growth removal might be a better predictor of shrub community composition in more arid areas where productivity is low, herbaceous vegetation is sparse, and shrubs compose a large percentage of white-tailed deer diets. Browse species composed $94 \%$ of annual deer diets in Nuevo Leon in northeastern Mexico, with blackbrush acacia composing $51 \%$ of diets (Ramirez et al. 1996). Blackbrush acacia composed $17.3 \%$ of the shrub community in Ramirez et al. (1997), while palatable species such as spiny hackberry and brasil composed only $0.7 \%$ and $0.6 \%$, respectively, of the shrub community. Implementing top growth removal techniques in more arid areas may impact the shrub community more adversely than managing brush in more productive sites like the Welder Wildlife Refuge.

\section{Literature Cited}

Asah, H. A., T. E. Fulbright, and M. L. Land. 1987. Effects of simulated browsing on spiny hackberry after top removal. Tex. J. of Agr. Natur. Resour. 1:16-18.

Basey, J. M., S. W. Jenkins, and P. E. Busher. 1988. Optimal central place foraging by beavers: Tree-size selection in relation to defensive chemicals of quaking aspen. Oecologia 76:278-282.
Box, T.W. 1961. Relationships between plants and soils of four range plant communities in South Texas. Ecol. 42:794-810.

Box, T. W. and J. Powell. 1965. Brush management techniques for improved forage values in South Texas. Trans. North Amer. Wildl. Conf. 30:285-296.

Bozzo, J. A., S. L. Beasom, and T. E. Fulbright. 1992. Vegetation responses to 2 brush management practices in South Texas. J. Range Manage. 45:170-175.

Bryant, J. P. and R. Julkunen-Tiitto. 1995. Ontogenic development of chemical defense by seedling resin birch: energy cost of defense production. J. Chem. Ecol. 21:883-896.

Bryant, J. P., P. B. Reichardt, and T. P. Clausen. 1992. Chemically mediated interactions between woody plants and browsing mammals. J. Range Manage. 45:18-24.

Bryant, J. P., F. D. Provenza, J. Pastor, P. B. Reichardt, T. P. Clausen, and J. T. du Toit. 1991. Interactions between woody plants and browsing mammals mediated by secondary metabolites. Annu. Rev. Ecol. Syst. 22:431-446.

Canfield, R.H. 1941. Application of the line interception method in range vegetation. J. For. 39:388-394.

Chamrad, A. D. and T. W. Box. 1968. Food habits of white-tailed deer in South Texas. J. Range Manage. 21:158-164.

Chapin, F. S. III, J. P. Bryant, and J. F. Fox. 1985. Lack of induced chemical defense in juvenile Alaskan woody plants in response to simulated browsing. Oecologia 67:457-459.

Drawe, D. L. 1968. Mid-summer diet of deer on the Welder Wildlife Refuge. J. Range Manage. 21:164-166.

Drawe, D. L. 1977. A study of five methods of mechanical brush control in south Texas. Rangeman's J. 4:37-39.

Drawe, D. L., A. D. Chamrad, and T. W. Box. 1978. Plant communities of the Welder Wildlife Refuge. Welder Wildl. Found. Contr. No. 5, Ser. B, Revised. Sinton, Tex.

Edenius, L., K. Danell, and H. Nyquist. 1995. Effects of simulated moose browsing on growth, mortality, and fecundity in Scots pine: relations to plant productivity. Can. J. For. Res. 25:529-535.

Flinn, R. C., C. J. Scifres, and S. R. Archer. 1992. Variation in basal sprouting in cooccurring shrubs: implications for stand dynamics. J. Veg. Sci. 3:125-128.

Forbes, T. D. A., I. J. Pemberton, G. R. Smith, and C. M. Hensarling. 1995. Seasonal variation of two phenolic amines in Acacia berlandieri. J. Arid Environ. 30:403-415.

Fulbright, T. E. 1987. Effects of repeated shredding on a guajillo (Acacia berlandieri) community. Tex. J. Agr. Natur. Resour. 1:32-33.

Fulbright, T. E. and S. L. Beasom. 1987. Long-term effects of mechanical treatments on white-tailed deer browse. Wildl. Soc. Bull. 15:560-564.

Fulbright, T. E. and R. B. Taylor. 2001. Brush management for white-tailed deer. 
Caesar Kleberg Wildlife Research Institute and Texas Parks and Wildlife, Joint Publication, Kingsville and Austin, Tex.

Guckian, W. J. and R. N. Garcia. 1979. Soil survey of San Patricio and Aransas counties, Texas. USDA, SCS, Washington, D.C.

Hatch, S. L., K. C. Gandhi, and L. E. Brown. 1990. Checklist of the vascular plants of Texas. Tex. Agr. Exp. Sta. Rep. MP-1655. College Station, Tex.

Illius, A. W., I. J. Gordon, D. A. Elston, and J. D. Milne. 1999. Diet selection in goats: A test of intake-rate maximization. Ecol. 80:1008-1018.

Naderman, J. F. 1979. Deer use of different size mechanically cleared openings in south Texas brush. M.S. Thesis, Texas Tech Univer. Lubbock, Tex.

Powell, J. and T. W. Box. 1966. Brush management influences preference values of south Texas woody species for deer and cattle. J. Range Manage. 19:212-214.

Ramirez, R. G., J. B. Quintanilla, and J. Aranda. 1997. White-tailed deer food habits in northeastern Mexico. Small Ruminant Res. 25:141-146.

Ramirez, R. G., G. F. W. Haenlein, A. Trevino, and J. Reyna. 1996. Nutrient and mineral profile of white-tailed deer (Odocoileus virginianus, texanus) diets in northeastern Mexico. Small Ruminant Res. 23:7-16.
Reichardt, P. B., J. P. Bryant, T. P. Clausen, and G. Wieland. 1984. Defense of winterdormant Alaska paper birch against Snowshoe hare. Oecologia 65:58-59.

SAS Institute, Inc. 1989. SAS user's guide: statistics. 1989 edition. SAS Institute Inc., Cary, N. C.

Scifres, C. J. 1980. Brush management. Principles and practices for Texas and the Southwest. Texas A\&M Univ. Press, College Station, Tex.

Scifres, C. J. and W. T. Hamilton. 1993. Prescribed burning for brushland management: The south Texas example. Texas A\&M Univ. Press, College Station, Tex.

Scifres, C. J., J. L. Mutz, and G. P. Durham. 1976. Range improvement following chaining of south Texas mixed brush. J. Range Manage. 27:462-465.

Schindler, J. R. 2000. Role of spinescence and secondary compounds in white-tailed deer preference of shrubs in burned and mowed areas in south Texas. M.S. Thesis, Texas A\&M University-Kingsville. Kingsville, Tex.

Snyder, J. D. and R. A. Janke. 1976. Impact of moose browsing on boreal-type forests of Isle Royale National Park. Amer. Mid. Natur. 95:79-92.
Stewart, K. M., T. E. Fulbright, and D. L. Drawe. 2000. White-tailed deer use of clearings relative to forage availability. J. Wildl. Manage. 64:733-741.

Vallentine, J. F. 1980. Range developments and improvements. Second edition. Brigham Young Univ. Press, Provo, Ut.

Welch, T. G., R. P. Smith, and G. A. Rasmussen. 1985. Brush management technologies. pp 15-24 In: Integrated brush management systems for south Texas: development and implementation. Tex. Agr. Exp. Sta. Bull 1493, Tex. A\&M Univ., College Station, Tex.

Westoby, M. 1974. An analysis of diet selection by large generalist herbivores. Amer. Natur. 108:290-304

Yoakum, J., W. P. Dasmann, H. R. Sanderson, C. M. Nixon, and H. S. Crawford. 1980. Habitat improvement techniques, p. 329-403. In: S. D. Schemnitz (ed.), Wildlife management techniques. Fourth edition. The Wildl. Soc., Washington, D.C. 